\title{
K-RAS Protein Vaccine
}

National Cancer Institute

\section{Source}

National Cancer Institute. K-RAS Protein Vaccine. NCI Thesaurus. Code C2067.

A vaccine composed of tumor-associated antigen, mutant K-ras, which produces both a cytotoxic and helper $\mathrm{T}$ cell response to challenge tumor cells expressing the relevant $\mathrm{K}$ ras oncogene. $(\mathrm{NCl})$ 